\title{
Scots pine responses to number and density of inoculation points with Leptographium wingfieldii Morelet, a bark beetle-associated fungus
}

\author{
Luc Croiséa,b, François Lieutier ${ }^{b *}$, Erwin Dreyer ${ }^{\mathrm{a}}$ \\ a Unité écophysiologie forestière, Inra, Centre de Nancy, 54280 Champenoux, France \\ ${ }^{\mathrm{b}}$ Station de zoologie forestière, Inra, Centre d'Orléans, 45160 Ardon, France
}

(Received 8 April 1997; accepted 21 August 1997)

\begin{abstract}
The effects of different densities and total distribution of inoculation points with Leptographium wingfieldii, a fungus associated with the bark beetle Tomicus piniperda, were investigated in Scots pine (Pinus sylvestris). During April 1993, 40 8-year-old Scots pine trees were inoculated into the trunk and until the cambium, at breast height. Inoculation points were distributed over a circular belt of $20,40,70$ and $100 \mathrm{~cm}$ width, at two densities (200 and $400 \mathrm{~m}^{-2}$ ). Three months after inoculation, the average length of the induced reaction zone was recorded on the external side of the phloem. The fraction of sapwood section that appeared blue-stained, desiccated or soaked with resin was also measured. The length of the visible, induced reaction zone in the phloem was affected neither by inoculation density nor by width of the inoculation belt. Similarly, the fraction area of damaged sapwood was small and constant at $200 \mathrm{~m}^{-2}$. It increased significantly only at the highest density $\left(400 \mathrm{~m}^{-2}\right)$ as a function of belt width, reaching $70 \%$ at $100-\mathrm{cm}$ width. It is concluded that: i) the average length of the induced reaction zone in the phloem is insensitive to inoculation density, and ii) the importance of damage in the sapwood is increasing only at inoculation densities above $400 \mathrm{~m}^{-2}$ over a sufficiently large area. This result is discussed in relation to the physiological meaning of the different symptoms, and in relation to the concept of threshold of attack density to explain why pine trees are affected only when the density of bark beetle attacks overrides this limit. (Iㅛra/Elsevier, Paris.)
\end{abstract}

Pinus sylvestris / bark beetle / Leptographium wingfieldii / inoculation density / number of inoculation points / phloem / induced reaction zone / sapwood / blue staining / dry sap$\operatorname{wood} /$ resin-soaked sapwood

Résumé - Réponses du pin sylvestre à la densité et au nombre de points d'inoculation réalisés avec Leptographium wingfieldii Morelet, un champignon associé aux scolytes. Les effets de la densité d'inoculation avec Leptographium wingfieldii (un champignon associé au scolyte Tomicus piniperda) et de l'augmentation du nombre de points d'inoculation, ont été étudiés sur

\footnotetext{
* Correspondence and reprints

E-mail: lieutier@orleans.inra.fr
} 
le pin sylvestre (Pinus sylvestris). En avril 93, quarante pins sylvestres âgés de 8 ans ont été inoculés dans le tronc à $1,30 \mathrm{~m}$. Les inoculations étaient réparties sur des ceintures de 20,40,70 ou $100 \mathrm{~cm}$ de largeur, avec deux densités (200 et $400 \mathrm{~m}^{-2}$ ). Trois mois après inoculation, la longueur des zones de réaction induites a été mesurée sur le côté externe du liber. Les fractions de section d'aubier bleui, desséché, ou imprégné de résine ont également été mesurées. La longueur de la zone de réaction visible dans le liber n'a été affectée ni par la densité d'inoculation, ni par la largeur des ceintures d'inoculations. De la même manière, la fraction d'aubier affectée est restée faible et constante à 200 inoculations $\mathrm{m}^{-2}$. En revanche, elle a augmenté de manière très importante en fonction de la largeur de ceinture d'inoculation pour la densité d'inoculation de $400 \mathrm{~m}^{-2} ; 70 \%$ de surface d'aubier étant affecté pour une ceinture de $100 \mathrm{~cm}$ de largeur. Deux conclusions sont déduites de ces résultats : $i$ ) la longueur de la zone de réaction induite dans le liber ne dépend pas de la densité d'inoculation, et ii) l'importance des dégâts dans l'aubier augmente uniquement pour des densités d'inoculations au dessus de $400 \mathrm{~m}^{-2}$ et des ceintures d'inoculations suffisamment larges. Ce résultat est discuté en fonction de la signification physiologique des différents symptômes, et en fonction du concept de seuil critique de densité d'attaque, pour tenter d'expliquer pourquoi la survie des pins est affectée uniquement quand la densité d'attaques de scolytes dépasse cette limite. (๑ Inra/Elsevier, Paris.)

Pinus sylvestris / scolyte / Leptographium wingfieldii / densité d'inoculations / nombre d'inoculations / liber / zone de réaction induite / aubier / bleuissement / dessèchement d'aubier / imprégnation de résine

\section{INTRODUCTION}

Bark beetles generally induce significant damages only when their attacks occur at a rather high density on a single tree. This fact led Berryman [2] to define a threshold of bark beetle attack density above which trees are severely affected and may die. Fungi associated with bark beetles may mimic this behaviour when inoculated directly into the trunk $[4,17$, $27,30]$. In the phloem, they induce an elliptical reaction zone surrounding each point of attack; heavy accumulation of resin and secondary metabolites occurs in this zone that gradually turns into a necrotic zone within which aggressors are confined $[2,6,21,27]$. In the sapwood, fungi may promote blue staining and tissue drying $[4,6]$. Nevertheless, and similar to that observed with beetle attacks, inoculation with such fungi has detrimental effects in the sapwood only when performed above a threshold density of inoculation points [30].
When inoculated into the bole of Scots pine (Pinus sylvestris), the fungus Leptographium wingfieldii, associated with the bark beetle Tomicus piniperda, is able to induce important reaction zones in which large accumulations of monoterpenes [10], resinic acids [19] and phenols $[22,23]$ occur. The effects of massive inoculation with this fungus have been investigated in Scots pine by Solheim et al. [30], who found that blue staining occurred in the sapwood only above a threshold of 400-800 inoculation points $\mathrm{m}^{-2}$. In the same experiment, $L$. wingfieldii killed vigorous Scots pines when inoculated at a density of 800 points $\mathrm{m}^{-2}$ over a $60-\mathrm{cm}$ wide band, while severely pruned trees were killed by an inoculation density of $400 \mathrm{~m}^{-2}$. In addition to the importance of attack density, it has been suggested that the total number of attacks could be of consequence for the outcome of the infection in Norway spruce $[4,25]$. This hypothesis has been documented by Christiansen and Berryman [5] in Norway spruce, but no information was available 
until now for Scots pine. Other than these observations, the existence of a threshold of inoculation density is still poorly supported by experimental evidence in Scots pine.

The present study aimed at testing the response of Scots pine trees to artificial inoculations with $L$. wingfieldii as modulated by two factors: i) density, and ii) total number of inoculation points. Results were expected to provide approximate values for the threshold of inoculation density in the case of young Scots pines, and to allow further research on the effect of environmental factors such as drought on Scots pine resistance to bark beetle-associated fungi.

\section{MATERIALS AND METHODS}

\subsection{Experimental layout}

During April 1993, 40 young Scots pine (Pinus sylvestris L.) growing in the forest of Orléans (Loiret, central France) were selected in the plot $\mathrm{n}^{\circ} 531$ which was flat, and on an homogenous soil. They were 8 years old, $3.5 \mathrm{~m}$ high, and diameter at breast height was around $6 \mathrm{~cm}$ in all cases. Dead lateral branches were pruned up to $1.80 \mathrm{~m}$, and the inoculations were made at breast height $\left(\mathrm{D}_{130}\right)$, on May 10 and 11, under eight different conditions: two densities of inoculation points distributed over belts of four different widths (table I), with a staggered disposition in order to avoid coalescence of the induced reaction zones in the phloem. Spacing between inoculation points was $7 \mathrm{~cm}$ at $200 \mathrm{~m}^{-2}$ and $5 \mathrm{~cm}$ at $400 \mathrm{~m}^{-2}$.

\subsection{Inoculation of the fungus, and measurement of sapwood and phloem reactions}

L. wingfieldii was collected from bark beetle galleries in the forest of Orléans, and grown on a malt agar medium as a monospore strain. At each inoculation point, bark and phloem were removed with a $5-\mathrm{mm}$ diameter cork borer, and a 5-mm diameter disc of a 3-weekold malt agar culture was inserted, with the fungus side close to the sapwood. Thereafter, the bark plug was returned to maintain the mycelium, and to avoid contamination [32].

Three months after inoculation, the trees were felled, and three stem discs were cut in the middle and close to both ends of the inoculated section of each stem. Areas of bluestained, dried and resin-soaked sapwood were

Table I. Experimental design used to assess the critical threshold of inoculation density on Scots pines inoculated with Leptographium wingfieldii in the forest of Orléans.

\begin{tabular}{lccccc}
\hline \multirow{2}{*}{$\begin{array}{c}\text { Density of } \\
\text { inoculation points }\left(\mathrm{m}^{-2}\right)\end{array}$} & \multicolumn{4}{c}{ Width of inoculation belts (cm) } \\
\cline { 3 - 6 } & 20 & 40 & 70 & 100 \\
\hline \multirow{2}{*}{$\begin{array}{c}\text { No. of trees } \\
\text { Sapwood diameter }(\mathrm{cm})\end{array}$} & $6.11(0.13)$ & $5.99(0.13)$ & $5.69(0.30)$ & $5.65(0.12)$ \\
& No. of inoculation points & 9 & 18 & 31 & 44 \\
$400 \quad$ No. of trees & 5 & 5 & 5 & 5 \\
& Sapwood diameter $(\mathrm{cm})$ & $6.01(0.19)$ & $6.30(0.19)$ & $5.66(0.17)$ & $5.56(0.26)$ \\
& No. of inoculation points & 18 & 35 & 62 & 88 \\
\hline
\end{tabular}

Numbers of inoculation per tree were calculated on the basis of an average circumference of $22 \mathrm{~cm}$. Mean values \pm standard errors. 


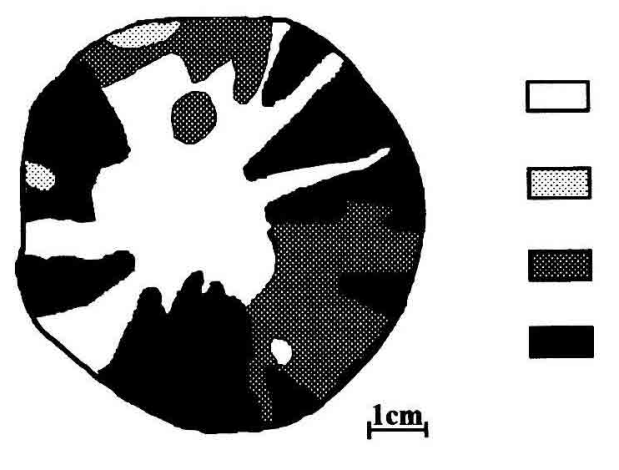

Conductive sapwood

Resin soaked sapwood (Rs)

Dried sapwood (D)

Blue-stained sapwood (Bs)

Figure 1. Example of stem section from a Scots pine inoculated with Leptographium wingfieldii at a density of 400 points. $\mathrm{m}^{-2}$ showing the distribution of sapwood soaked with resin, dried or blue stained, 3 months after inoculation.

measured on the discs (figure 1). Data were obtained by drawing the areas on a transparent paper and by measuring them with a planimetre $(\Delta \mathrm{T}$ area metre, $\Delta \mathrm{T}$ Devices, Cambridge, UK). The outer bark was removed at around 10 inoculation points in each tree, and the visible length of the induced reaction zones was measured at the external side of the phloem.

\subsection{Decline assessment}

Before felling the trees, we visually assessed the degree of yellowing in the crown, and ordered them according to three classes: 1) completely green needles, 2) faint yellowing distributed over the whole crown and 3) severe yellowing of the whole crown.

\subsection{Statistical methods}

Mean values of damage extent were calculated in each tree, and resulting values were compared between modalities. Means are presented with their standard error. Analysis of variance (ANOVA) was achieved using SAS software (SAS Institute, Cary, NC, USA), and differences between means were tested using multiple comparison tests of Bonferroni $(\alpha=$ $0.05, n=5$ ).

\section{RESULTS}

Three months after the inoculation with L. wingfieldii, several trees displayed external symptoms of decline, with severe needle yellowing; in particular, trees exposed to the highest inoculation density $\left(400 \mathrm{~m}^{-2}\right)$ were severely affected, while those inoculated at $200 \mathrm{~m}^{-2}$ remained almost unaffected (figure 2). The induced reaction zone surrounding inoculation points in the phloem was approximately $10 \mathrm{~cm}$ long; this length remained unaffected by density or total number of inoculation points (figure 3).

The total area of damaged sapwood increased significantly with inoculation density and number of inoculations 

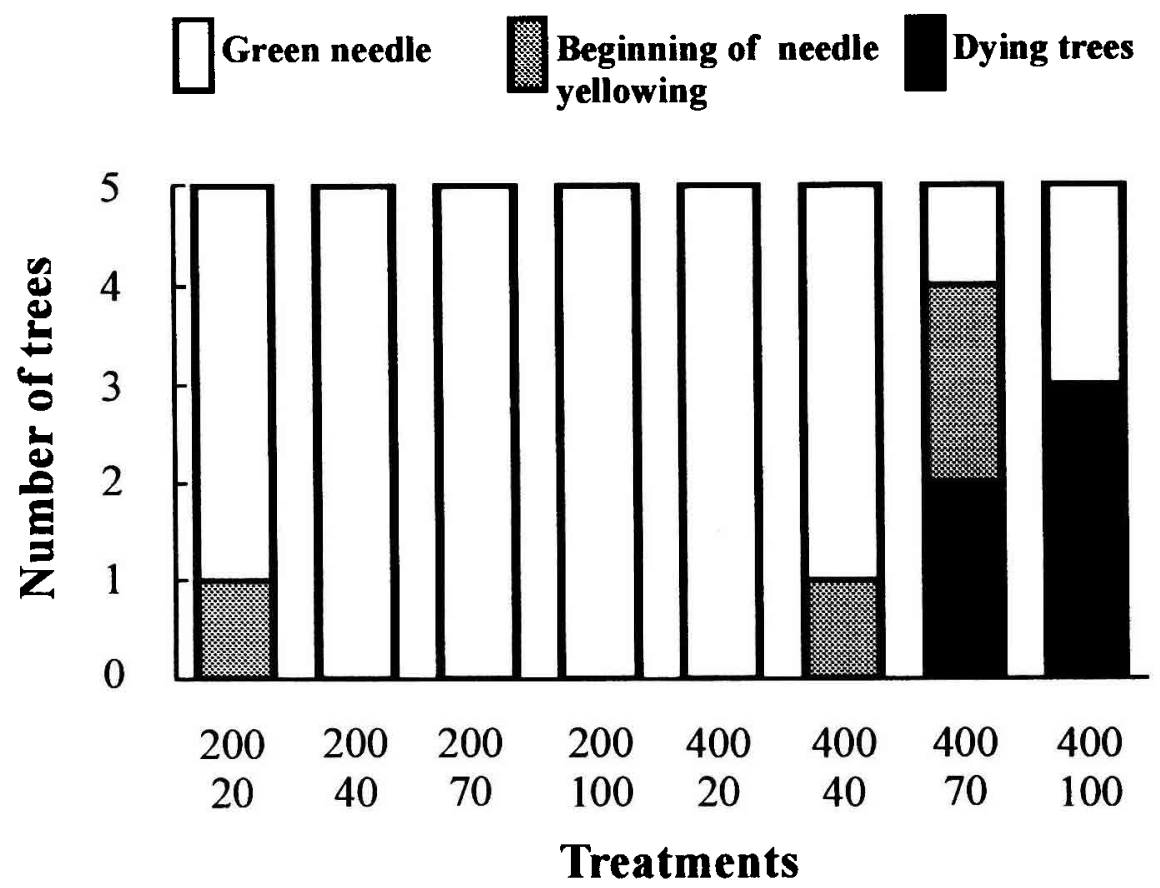

Figure 2. Number of Scots pine trees displaying perfectly green needles, faint or severe needle yellowing 3 months after inoculation with Leptographium wingfieldii. Treatments included inoculation density ( 200 or $400 \mathrm{~m}^{-2}$, upper X-axis label) and width of the inoculation belts $(20,40$, 70 or $100 \mathrm{~cm}$, lower $\mathrm{X}$-axis label).

(figure 3). Resin-soaked and desiccated sapwood areas were around $5-15 \%$ in response to all treatments, and did not display any change with density or number of inoculations. The fraction of blue-stained sapwood was very low at $200 \mathrm{~m}^{-2}$ for all belt widths. It increased dramatically at $400 \mathrm{~m}^{-2}$ for the highest belt widths (figure 3 ). In fact, the interaction between the two factors (density and belt width) was significant $(P>F 0.0135)$ : the increase due to higher densities was only detectable above $70 \mathrm{~cm}$ belt width.

Despite the lack of effect of treatments on the length of the induced reaction zone, a significant correlation between this parameter and the damaged sapwood area was found (table II). As expected, the percent of resin-soaked and dried sapwood were correlated as well as with the percent total damaged sapwood.

\section{DISCUSSION}

L. wingfieldii is known to display a high pathogenicity and to have the capability to kill Scots pine trees at least 1 year after inoculation at high densities $[21,29$, 30]. The effects of artificial inoculation of a strain of this species into the trunk of young trees at two densities and over four belt widths were very contradictory. High- 
(uว) วuoz

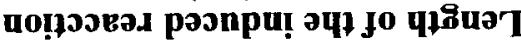

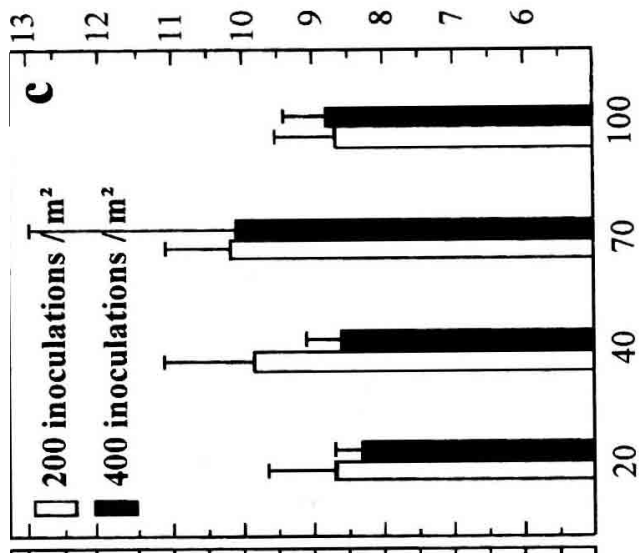

4.

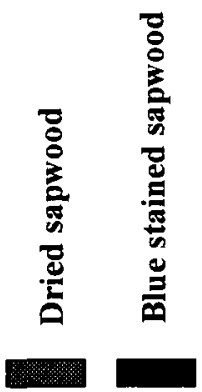

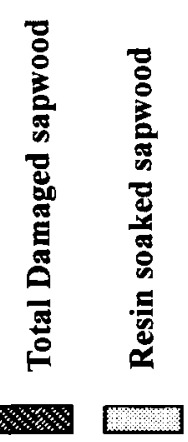

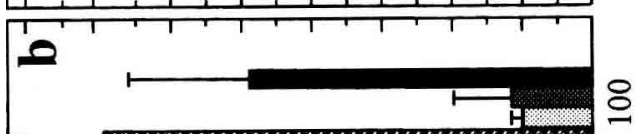

อ

e $\frac{7}{3} \frac{5}{2}$

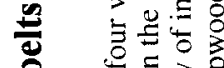

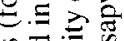
竞焉造 을 등ㅎㅇ

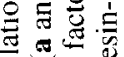
$\exists=$

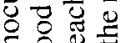
它客官 苏

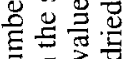
$\exists>$ 을 㱐的 की 음 8 兵. 导

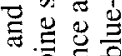
8 흔 z割 क 可 5 可 क व 政 要过

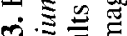
눈 50 का 
Table II. Correlation matrix for damage extent in the phloem and in the sapwood observed 3 months after inoculation of Scots pines with Leptographium wingfieldii.

\begin{tabular}{llllll}
\hline & Td & Bs & D & Rs & Irzl \\
\hline Td & 1 & & & & \\
Bs & $0.474 * *$ & 1 & & & \\
D & $0.878^{* *}$ & $0.118 n . s$. & 1 & & \\
Rs & $0.630^{* *}$ & 0.081 n.s. & $0.389^{*}$ & 1 & 1 \\
Irzl & $0.629 *$ & $0.143 n . s$. & $0.560^{* *}$ & $0.553^{* *}$ & 1 \\
\hline
\end{tabular}

*Correlation significant at $P<0.05$; * significant at $P<0.001$. Td, total damaged sapwood ( $=\mathrm{Bs}+\mathrm{D}+\mathrm{Rs}$ ); Bs, blue-stained sapwood; D, desiccated sapwood; Rs, resin-soaked sapwood; Irzl, induced reaction zone length; n.s., not significant.

est densities and largest belts resulted in visible yellowing, but did not induce tree mortality after 3 months. A similar observation was previously reported by Bois [3], who inoculated young Scots pine at a high density $\left(400 \mathrm{~m}^{-2}\right)$ and on $1-\mathrm{m}$ belt width. In fact, our observations correspond to early events of tree decline, and the lack of tree death after 3 months cannot be used to affirm that the density of inoculation points was too low to induce tree decline. In fact, Solheim et al. [30] observed tree death 1 year after inoculation at a density of $400 \mathrm{~m}^{-2}$.

Despite this lack of mortality, important damage (i.e. occurrence of large areas of blue-stained, resin-soaked and desiccated sapwood) was induced in the sapwood and its extent depended heavily on the inoculation density. The highest density promoted extended damage. Such results are in agreement with inoculation density responses reported for the same fungus-tree model [30]. Beyond this very general observation, a careful analysis of symptoms revealed differential effects. Blue staining increased dramatically with inoculation density, whereas resin soaking or desiccation extension did not vary significantly. Development of blue staining is the direct manifestation of the pres- ence of the pigmented fungal hyphae [1, $11,13]$ that preferentially develop in the ray parenchyma and resin ducts $[1,20]$. Tracheids are colonized secondarily, and the progress of the hyphae occurs via bordered pits or through direct penetration of the walls [20]. The rate of fungal colonization is slow in the nutrient-rich ray cells and faster in the tracheids. Development of dried, non-conducting zones in the sapwood of conifers was frequently observed in response to fungal invasion $[7,8]$. They are generally located at the margin of the stained areas and elaborated in response to fungal activity $[12,28]$. It is assumed that desiccation of the sapwood occurs before blue staining, i.e. before penetration of the fungus into the medullar rays [15]. In addition, desiccation seems to be specifically induced by the fungus; a simple inoculation with sterile agar has no effect [12]. Chemicals such as oxalic acid [8] or others $[9,14]$ are produced by several fungi and may play a role in inducing embolization and subsequent desiccation of sapwood at a distance from the zone where fungi are present.

Our observations fit into this general frame. The fact that desiccated sapwood was relatively stable while blue staining increased significantly only above an inoc- 
ulation density of $400 \mathrm{~m}^{-2}$ with a width of $70 \mathrm{~cm}$ suggests that generalized colonization of sapwood probably occurs only above a severe inoculum constraint. We may hypothesize that the progression of L. wingfieldii in the sapwood is accompanied by a gradual desiccation of wood tissues that are secondarily invaded by mycelia. As such, we may state that a threshold of inoculation density must be reached before the invasion of the sapwood by mycelial strains is possible. The sequence of events leading to the infection stage observed in our stem sections needs, nevertheless, to be better documented by sequential anatomical observations during the course of infection.

The impact of the total number of inoculation points at a given density has been suggested by Christiansen [4], Mulock and Christiansen [25] and Horntvedt and Solheim [16]. More recently, Christiansen and Berryman [5] observed that the bluestained sapwood cross-sectional area was dependent on the inoculated belt width in Norway spruce. They evidenced that at an inoculation density of $400 \mathrm{~m}^{-2}$ with Ceratocystis polonica, blue staining was greatly enhanced as soon as the belt width overcame $50 \mathrm{~cm}$ in a susceptible clone, while in two resistant ones, a width above $90 \mathrm{~cm}$ was needed to obtain similar damage. Our results clearly confirm the importance of the total number of inoculation points, as a large increase of blue staining was observed in the sapwood with an increasing amount of inoculation points, at a density of $400 \mathrm{~m}^{-2}$. Nevertheless, we also showed that this response depended on inoculation density and was not detected at a lower density of $200 \mathrm{~m}^{-2}$.

Finally, our experiment suggests that the threshold of inoculation density with $L$. wingfieldii is close to $400 \mathrm{~m}^{-2}$ on a belt width of $100 \mathrm{~cm}$. Above such conditions, death of young Scots pines may be expected. This value is close to the threshold of $600 \mathrm{~m}^{-2}$ over a $60-\mathrm{cm}$ belt width shown by Solheim et al. [30] with the same species but somewhat older and taller trees ( 20 years, $5.5 \mathrm{~m}$ ). In the same way, the critical threshold of inoculation density probably depends on tree vigour. For instance, Långström et al. [18] showed that pruned Scots pine were more heavily affected by bark beetle (Tomicus piniperda) attacks than unpruned ones. Mahoney [24], Raffa and Berryman [27], and Waring and Pitman [31] observed that Pinus contorta trees with a low sapwood productivity were more sensitive to Dendroctonus ponderosae attacks than trees with a high sapwood productivity. Similar results were obtained with Picea abies attacked by Ips typographus [25]. Using the technique of mass inoculation with Ceratocystis polonica, Christiansen [4] showed that suppressed trees appeared more susceptible than more vigorous trees. It is therefore extremely difficult to extrapolate our results to other stands of Scots pine without additional information on the relationships between growth conditions, tree vigour and susceptibility to $L$. wingfieldii.

A last but interesting result of our study lies in the stability of the length of the induced reaction zone in the phloem, which was significantly affected neither by the density nor by the total amount of inoculation points. This observation is similar to those made by Solheim et al. [30] and by Bois [3]. It points to a relative independence between the responses observed in the phloem and the spread of the fungus in the sapwood. The slight correlation found between this parameter and the total damage in the sapwood tempers this assertion.

\section{ACKNOWLEDGEMENTS}

The authors are grateful to the "Office National des Forêts' for providing the Scots pine stand in the forest of Orléans, and the technical help of J. Garcia and P. Romary is 
acknowledged. We thank C. Delatour for improving our initial manuscript, and two anonymous referees for helpful comments.

\section{REFERENCES}

[1] Ballard R.G., Walsh M.A., Cole W.E., The penetration and growth of blue-stain fungi in the sapwood of lodgepole pine attacked by mountain pine beetle, Can. J. Bot. 62 (1984) 1724-1729.

[2] Berryman A.A., Biological control, thresholds, and pest outbreaks, Environ. Entomol. 11 (1982) 544-549.

[3] Bois E., Rôle des composés phénoliques dans la résistance du Pin sylvestre aux attaques de Scolytidae et de leurs champignons associés Ph.D. thesis, University of Orléans, France, $1996,136 \mathrm{p}$.

[4] Christiansen E., Ceratocystis polonica inoculated in Norway spruce: blue-staining in relation to inoculum density, resinosis and tree growth, Eur. J. For. Pathol. 15 (1985) 160-167.

[5] Christiansen E., Berryman A.A., Norway spruce clones vary widely in their susceptibility to a bark beetle-transmitted blue-stain fungus, in: Hain F.P., Salom S.M., Ravlin W.F. Payne T.L., Raffa K.F. (Eds.), Behavior, Population Dynamics and Control of Forest Insects, Proceedings of the International Union of Forestry Research Organizations, working party S2, 07-06 Maui, Hawaii, February 1994, Ohio State University Press, Columbus, 1995.

[6] Christiansen E., Waring R.H., Berryman A.A., Resistance of conifers to bark beetle attack: searching for general relationships, For. Ecol. Manag. 22 (1987) 89-106.

[7] Coutts M.P., The formation of dry zones in the sapwood of conifers. I. Induction of drying in standing trees and logs by Fomes annosus and extracts of infected wood, Eur. J. For. Pathol. 6 (1976) 372-381.

[8] Coutts M.P., The formation of dry zones in the sapwood of conifers. II. The role of living cells in the release of water, Eur. J. For. Pathol. 7 (1977) 6-12.

[9] DeAngelis J.D., Hodges J.D., Nebeker T.E., Phenolic metabolites of Ceratocystis minor from laboratory cultures and their effects on transpiration in loblolly pine seedlings, Can. J. Bot. 64 (1986) 151-155.

[10] Delorme L., Lieutier F., Monoterpene composition of the preformed and induced resins of Scots pine, and their effect on bark beetles and associated fungi, Eur. J. For. Pathol. 20 (1990) 304-316.

[11] Gibbs J.N., The biology of Ophiostomatoid fungi causing sapstain in trees and freshly cut logs, in: Wingfield M., Seifert K.A., Weber J.F. (Eds.), Ceratocystis and Ophiostoma, Taxonomy, Ecology and Pathogenicity, The American Phytopathological Society, St. Paul, Minnesota (17) 1993, pp. 153-160.

[12] Harding S., The influence of mutualistic blue stain fungi on bark beetle population dynamics, Ph.D. thesis, University of Copehagen, Denmark, 1989, 163 p.

[13] Hartig R., Die Zersetzungsercheinungen des Holzes der Nadelbaüme und der Eiche, Julius Springer, Berlin, 1878, 151 p.

[14] Hemingway W., McGraw G., Barras S.J., Polyphenols in Ceratocystis minor infected Pinus taeda: fungal metabolites, phloem and xylem phenols, J. Agric. Food Chem. 24 (1977) 717-722.

[15] Hobson K.R., Parmeter J.R., Wood D.L., The role of fungi vectored by Dendroctonus brevicomis Leconte (Coleoptera: Scolytidae) in occlusion of ponderosa pine xylem, Can. Entomol. 126 (1994) 277-282.

[16] Horntvedt R., Solheim H., Pathogenicity of Ophiostoma polonicum to Norway spruce: the effect of isolate age and inoculum dose, Medd. Norsk. Inst. Skogforsk. 44 (1991) 1-11.

[17] Horntvedt R., Christiansen E., Solheim H., Wang S., Artificial inoculation with Ips typographus-associated blue-stain fungi can kill healthy Norway spruce trees, Medd. Norsk. Inst. Skogforsk. 38 (1983) 1-20.

[18] Långström B., Hellqvist C., Ericsson A., Gref $R$., Induced defence reaction in Scots pine following stem attacks by Tomicus piniperda, Ecography 15 (1992) 318-327.

[19] Långström B., Solheim H., Hellqvist C., Gref R., Effects of pruning young Scots pines on host vigour and susceptibility to Leptographium wingfieldii and Ophiostoma minus, two bluestain fungi associated with Tomicus piniperda, Eur. J. For. Pathol. 23 (1993) 400-415.

[20] Liese W., Schmid R., Licht und elektronenmikroskopische Untersuchung über das Wachstum von Bläuepiltzen in Kiefern und Fichtenholz, Holz Roh. Werkst. 9 (1961) 329-337.

[21] Lieutier F., Cheniclet C., Garcia J., Comparison of the defence reactions of Pinus pinaster and Pinus sylvestris to attacks by two Bark beetles (Coleoptera : Scolytidae) and their associated fungi, Environ. Entomol. 18 (1989) 228-234.

[22] Lieutier F., Yart A., Jay-Allemand C., Delorme L., Preliminary investigations on phenolics as a response of Scots pine phloem to attacks by bark beetles and their associated fungi, Eur. J. For. Pathol. 21 (1991) 354-364.

[23] Lieutier F., Sauvard D., Brignolas F., Picron V., Yart A., Bastien C., Jay-Allemand C., Changes in phenolic metabolites of Scots-pine phloem induced by Ophiostoma brunneo-cil- 
iatum, a bark-beetle-associated fungus, Eur. J. For. Pathol. 26 (1996) 145-158.

[24] Mahoney R.L., Lodgepole pine/mountain pine beetle risk classification methods and their application, in: Berryman A.A., Amman G.D., Stark R.W., Kibbee D.L. (Eds.), Theory and Practice of Mountain Pine Beetle Management in Lodgepole Pine Forests, College of Forest Resource, Univ. of Idaho, Moscow, 1978, pp. $106-113$.

[25] Mulock P., Christiansen E., The threshold of successful attack by Ips typographus on Picea abies: a field experiment, For. Ecol. Manag. 14 (1986) 125-132.

[26] Raffa K.F., Berryman A.A., Physiological differences between lodgepole pines resistant and susceptible to the mountain pine beetle and associated microorganisms, Environ. Entomol. 11 (1982) 486-492.

[27] Raffa K.F., Berryman A.A., Physiological aspects of lodgepole pine wound responses to a fungal symbiont of the mountain pine beetle, Dendroctonus ponderosae (Coleoptera:
Scolytidae), Can. Entomol. 115 (1983) 723-734.

[28] Shain L., The response of sapwood of Norway spruce to infection by Fomes annosus, Phytopathology 61 (1971) 301-307.

[29] Solheim H., Långström B., Blue-stain fungi associated with Tomicus piniperda in Sweden and preliminary observations on their pathogenicity, Ann. Sci. For. 48 (1991) 149-156.

[30] Solheim H., Långström B., Hellqvist C., Pathogenicity of the blue-stain fungi Leptographium wingfieldii and Ophiostoma minus to Scots pine: effect of tree pruning and inoculum density, Can. J. For. Res. 23 (1993) 1438-1443.

[31) Waring R.H., Pitman G.B., Physiological stress in lodgepole pine as a precursor for mountain pine beetle attack, Z. Angew. Entomol. 96 (1983) 265-270.

[32] Wright E., A cork-borer method for inoculating trees, Phytopathology 23 (1933) 487-488. 